\title{
Granulometric characterization of sediments transported by surface runoff generated by moving storms
}

\author{
J. L. M. P. de Lima ${ }^{1,2}$, C. S. Souza ${ }^{2}$, and V. P. Singh ${ }^{3}$ \\ ${ }^{1}$ Department of Civil Engineering, Faculty of Science and Technology - Campus 2, University of Coimbra, 3030-788 \\ Coimbra, Portugal \\ ${ }^{2}$ Institute of Marine Research - Coimbra Interdisciplinary Centre, Coimbra, Portugal \\ ${ }^{3}$ Department of Biological and Agricultural Engineering, Texas A and M University, Scoates Hall, 2117 TAMU, College \\ Station, Texas 77843-2117, USA
}

Received: 8 May 2008 - Revised: 22 October 2008 - Accepted: 4 November 2008 - Published: 16 December 2008

\begin{abstract}
Due to the combined effect of wind and rain, the importance of storm movement to surface flow has long been recognized, at scales ranging from headwater scales to large basins. This study presents the results of laboratory experiments designed to investigate the influence of moving rainfall storms on the dynamics of sediment transport by surface runoff. Experiments were carried out, using a rain simulator and a soil flume. The movement of rainfall was generated by moving the rain simulator at a constant speed in the upstream and downstream directions along the flume. The main objective of the study was to characterize, in laboratory conditions, the distribution of sediment grain-size transported by rainfall-induced overland flow and its temporal evolution. Grain-size distribution of the eroded material is governed by the capacity of flow that transports sediments. Granulometric curves were constructed using conventional hand sieving and a laser diffraction particle size analyser (material below $0.250 \mathrm{~mm}$ ) for overland flow and sediment deliveries collected at the flume outlet. Surface slope was set at $2 \%, 7 \%$ and $14 \%$. Rainstorms were moved with a constant speed, upslope and downslope, along the flume or were kept static. The results of laboratory experiments show that storm movement, affecting the spatial and temporal distribution of rainfall, has a marked influence on the grain-size characteristics of sediments transported by overland flow. The downstreammoving rainfall storms have higher stream power than do other storm types.
\end{abstract}

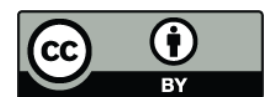

Correspondence to: J. L. M. P. de Lima (plima@dec.uc.pt)

\section{Introduction}

The soil material transported by overland flow is important for water quality management, environmental decision making, urban management and sustainability of ecosystems. The objective of this study is to enhance the understanding of water erosion factors and processes.

The influence of the spatial and temporal distribution of rainfall on surface runoff and associated transport processes on different types of ground cover has long been investigated. However, for a long time, all manner of difficulties have been encountered in characterizing and controlling with precision the parameters that influence runoff. Thus, experiments using rain simulators started to be carried out. Laboratory experiments allowed a better control of parameters and led to improved results. The benefits of using rain simulators for the characterization of surface runoff have been discussed by Meyer (1965), Bryan and Poesen (1989), Cerdà et al. (1997), among others. However, many studies did not take into account the effect of the movement of rainfall caused by the action of wind on runoff. Failure to consider the movement of rainfall (i.e., the combined action of wind and rain) can result in under- or over-estimation of peak discharge (e.g., Jensen, 1984; Singh, 1998; de Lima and Singh, 2002, 2003). The importance of the combined action of wind and rain, especially the changes in rainfall characteristics (e.g., spatial and temporal distribution, trajectory of drops) and runoff (e.g., height of runoff and speed), has been recognized by a number of investigators (e.g., Maksimov, 1964; Yen and Chow, 1968; Wilson et al., 1979; Erpul et al., 1998; Gabriels et al., 1997; Singh, 1998; de Lima and Singh, 1999; Erpul et al., 2000 and 2003, de Lima et al., 2003). Some investigators (e.g., de Lima and Singh, 2002) have thus considered the movement

Published by Copernicus Publications on behalf of the European Geosciences Union and the American Geophysical Union. 
of rainfall over basins, particularly upstream or downstream. They have found a significant influence of the direction of rainfall on runoff and sediment transport.

Erosion of soil by water is a natural phenomenon that influences the origin and dynamics of landscapes; it thus plays an important role in the evolution of ecosystems. Understanding the factors that affect water erosion are fundamental for planning and designing measures for soil conservation, particularly where the intensive use of soil has been degrading land and water. Erosion of soil by water is caused by the combined and the simultaneous effect of the processes of disaggregating soil aggregates by the impact of rain drops and runoff and then the transport of these aggregates by runoff (e.g., Römkens et al., 1997; Meyer, 1981). Any factor that influences runoff characteristics consequently affects the erosion of soil by water.

Although processes such as infiltration, runoff and water erosion have been extensively studied using rain simulators, the great majority of these studies used constant rainfall intensities, thus differing considerably from the characteristics of natural rainfall, which is highly variable in both time and space (e.g., Huff, 1967; Eagleson, 1978; Sharon, 1980; Willems, 2001). The spatial and temporal distribution of rainfall is one of the main factors affecting runoff on slopes.

This study attempts to characterize the grain-size distribution of sediments carried by runoff, allowing for the evaluation of the influence of rainfall storm movement (upstream, downstream or static) and of the soil flume gradient (which varied as $2 \%, 7 \%$ and $14 \%$ ) on the grain-size. This evolution, evaluated by grain-size distribution curves, was then related to the respective runoff hydrographs, thus identifying the part of the hydrograph with greater erosive impact on soil; this part could be the rising or falling limb or the peak discharge of the runoff hydrograph.

\section{Methodology}

The methodology used to conduct the experiments was divided into two phases: (i) Simulation of rainfall events and obtaining the hydrographs of direct runoff; and (ii) characterization of the transported sediments by runoff (e.g., temporal evolution and granulometry analysis).

\subsection{Rainfall simulator}

Erosion of soil by water has been studied extensively, both in the field and in laboratory, with rain simulators (e.g., Morgan, 1995). The rain simulator (Fig. 2) comprises a constant level reservoir, a pump, a system of hoses, a stand, 2 electric engines, 1 automatic control panel to control the speed at which the apparatus moves, and a sprinkler (nozzles from Spraying Systems Co.) fixed on a connecting rod in the stand $2.20 \mathrm{~m}$ above the surface of the flume.
The rainfall used in the laboratory experiments had the spatial distribution presented in Fig. 1 as a consequence of a constant pressure of 2 bar, corresponding to a discharge of $12 \mathrm{l} / \mathrm{min}$. To measure the rainfall intensity distribution under the rainfall simulator, 70 gauges were used in a $0.3 \times 0.3 \mathrm{~m}^{2}$ square grid of covering an area of $2.7 \mathrm{~m}$ long and $1.8 \mathrm{~m}$ wide. Given the flume area and the pre-established duration of rainfall, this discharge is the equivalent of a rainfall intensity of $138 \mathrm{~mm} / \mathrm{h}$, which, for Coimbra (Portugal), can be related to a return period of about 2 years. As in other natural situations, the spatial distribution of simulated rainfall is not uniform: in the catchment area affected by rainfall the intensity is higher in some parts and lower in others. This characteristic of rainfall has been described by Bras and Rodrigues-Iturbe (1976), Sivapalan and Wood (1986) and Willems (2001), and others.

Rainfall moving upstream and downstream at a constant speed was simulated over a laboratory soil flume. The rainfall movement was achieved by moving the wheeled stand holding the nozzle over the flume. The static rainfall had the nozzle mounted on the vertical line that contains the geometric centre of the flume.

The experimental apparatus was moved on wheels on a steel rail, powered by 2 electric motors. The speed of the rain simulator was kept at a constant speed of $1.97 \mathrm{~m} / \mathrm{min}$, which corresponds to a total of 3.3 litres of water falling on the flume surface. The duration of the static rainfall was determined so as to guarantee a rainfall volume equal to the moving rain events. It should also be noted that the laboratory experiments were performed without wind, and therefore do not entirely represent the real wind-driven rain conditions (no added horizontal wind component). This paper deals mainly with the spatial and temporal distribution of the rainfall, as a consequence of the movement of the rainfall simulators, which is one of the main factors affecting runoff on slopes.

\subsection{Soil flume}

The soil flume was made of zinc-coated iron and was $3.00 \mathrm{~m}$ long, $0.30 \mathrm{~m}$ wide and $0.10 \mathrm{~m}$ deep. The structure allowed the channel slope to be altered by means of adjustable screws. The surface flow was collected at the lower end of the flume. In this study both the type of rainstorm and the soil flume gradient were varied, the latter by using the following gradients: $2 \%, 7 \%$ and $14 \%$. The slope gradient is one of the critical factors controlling soil erosion caused by runoff (e.g., Bryan and Poesen, 1989).

The sedimentary material used in the laboratory experiments as "soil" was taken from the right bank of the Mondego River, in Coimbra, Portugal. The clastic material was readily available and shows, in situ, important signs of water erosion. The material was taken from a Triassic outcrop, consisting mainly of quartz and feldspar, but also included quartzite, mica and clay minerals. The soil consists of $7 \%$ 

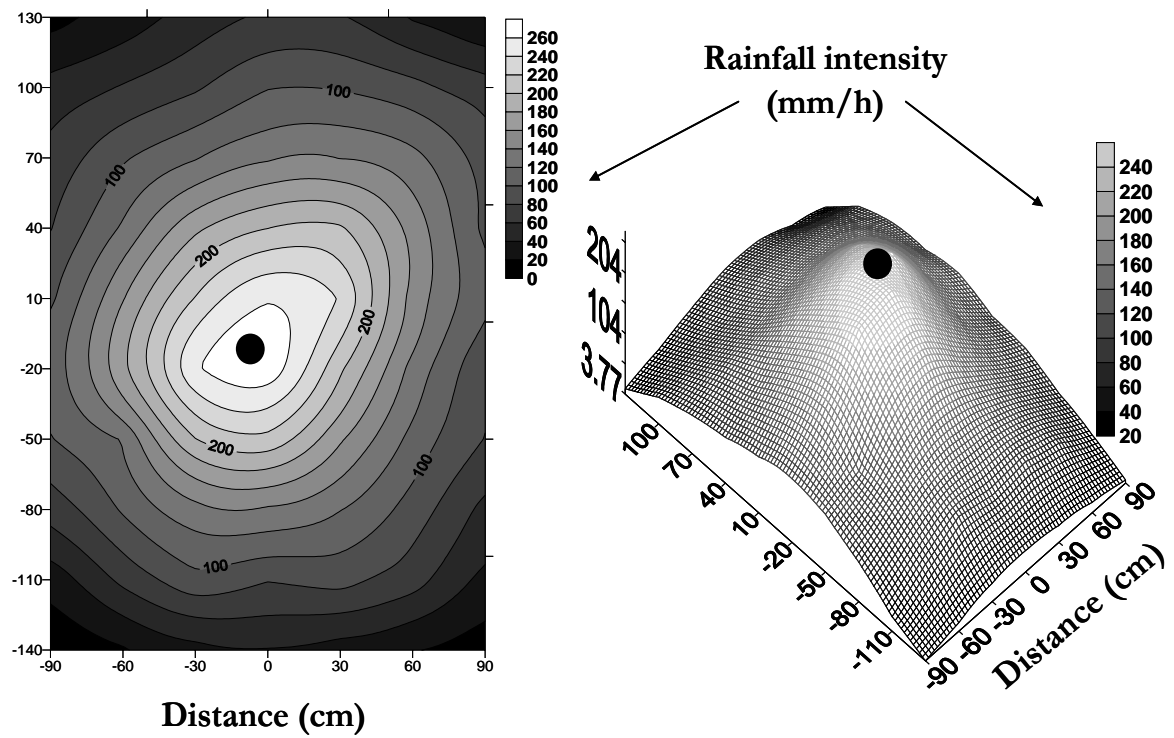

Fig. 1. Spatial distribution of rainfall under a nozzle: Left: 2-D representation and Right: 3-D distribution. • Location of vertical that contains the nozzle.

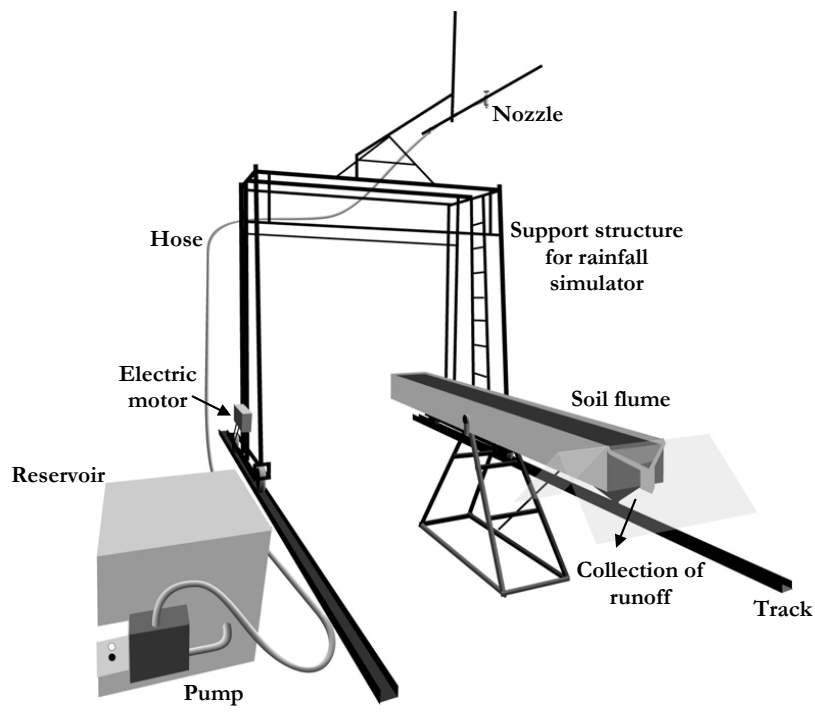

Fig. 2. Laboratory set-up.

clay, $9 \%$ silt and $84 \%$ sand and gravel. The soil texture information is listed in Table 1.

\subsection{Laboratorial procedure}

During experimentation, it was observed that there was always a larger quantity of fine particles transported in the first simulated rains; so each rainfall type was repeated 4 times for observing differences in granulometric characteristics. To ensure identical initial conditions, the soil material placed in the flume was replaced with original soil before each rain
Table 1. Particle size distribution of the experimental soil.

\begin{tabular}{lll}
\hline Material & Particle Size $(\mathrm{mm})$ & Distribution $(\%)$ \\
\hline Clay & $0-0.0062$ & 6.64 \\
Silt & $0.0062-0.0233$ & 3.23 \\
& $0.0233-0.1500$ & 6.30 \\
Sand and Gravel & $0.1500-0.5000$ & 31.60 \\
& $0.5000-4.7600$ & 40.72 \\
& $4.7600-19.1000$ & 11.51 \\
\hline
\end{tabular}

type and was subjected to a standard treatment. The soil was first sieved to remove coarser particles and organic material, and then placed in the soil flume in a series of layers to achieve a $0.10 \mathrm{~m}$ thick layer of uniform depth. Before each repetition the surface layer's water content was controlled by imposing a $30 \mathrm{~min}$ interval between simulated rainstorm events. The volumetric soil water content was approximately $20 \%$ (determined by Time-Domain-Reflectometer measurements) just before the start of each storm event.

The repetition for each type of rainfall was identical. In this study, identical rainfall means events of the same rainfall intensity, the same pattern and the same equivalent drop diameter distribution, and which move in the same direction and at the same speed (de Lima and Singh, 2002). Overland flow and sediment loss caused by each rainfall event were measured by collecting samples every $15 \mathrm{~s}$ in metal containers placed at the downstream end of the soil flume. The starting measurement time for each storm event corresponded to the initiation of overland flow at the flume outlet. Rainfall 


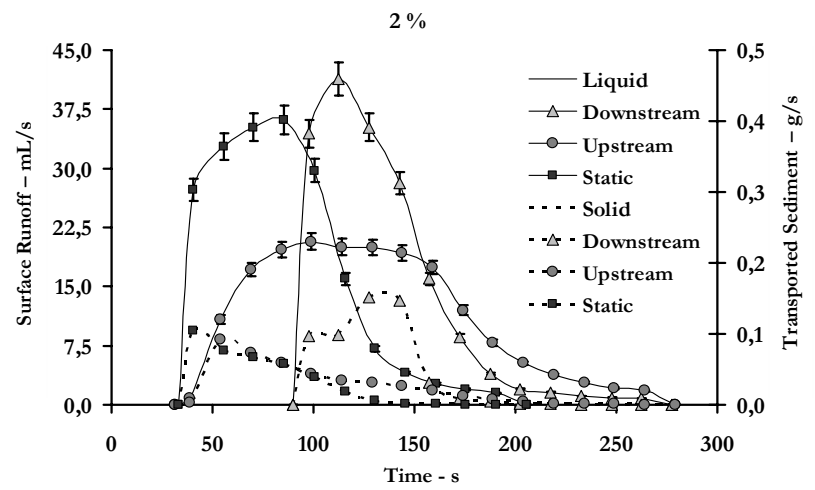

$7 \%$

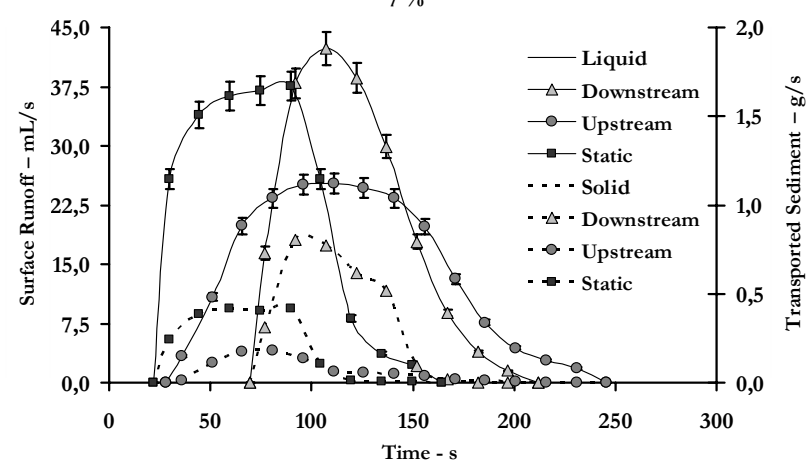

$14 \%$

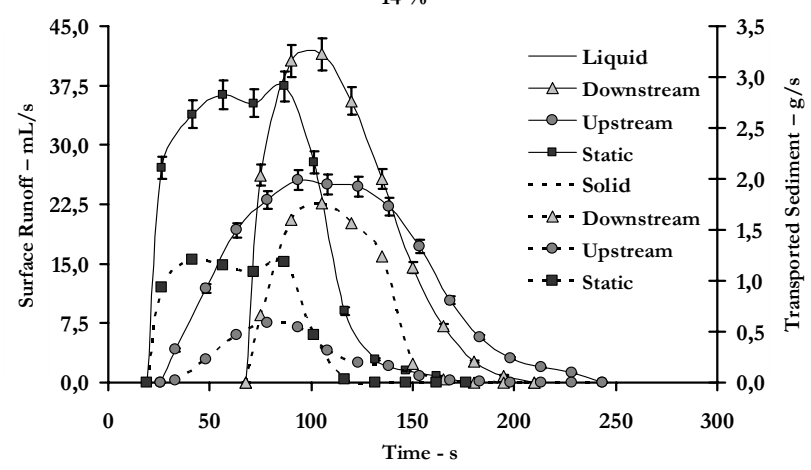

Fig. 3. Runoff hydrographs and respective eroded material for different slopes $(2 \%, 7 \%$ and $14 \%)$ and for the 3 types of storms studied (downstream, upstream and static).

was simulated under free draining conditions. Solid weight was obtained by drying the samples in order to characterize the temporal evolution of runoff and sediment discharge. The amount of sediment transported by overland flow was estimated by low temperature oven drying of runoff samples.

After drying the runoff samples, the transported sediments underwent grain-size characterization in order to evaluate how their texture evolved over time. There were two distinct phases in this step: one using the laser diffraction particle size analyzer (for particles finer than $0.25 \mathrm{~mm}$ ), and the other using conventional sieving (for particles coarser than $0.25 \mathrm{~mm}$ ). The material whose particle size was less than $0.25 \mathrm{~mm}$, suspended in the liquid medium, was analyzed by the equipment, and the other fraction was dried and sieved conventionally.

Soil detachment significantly changes with windward and leeward slopes under wind-driven rains This means that, apart from the transport capacity of the overland flow, the delivery of the detached particles to the flow will be different when the rainfall is upstream-moving from when it is downstream-moving (Erpul, 2003a, 2005, 2008). In fact the experiments do not entirely represent wind-driven rains. The paper deals more with the spatial and temporal distribution of the rainfall which is a consequence of the combined action of wind and rain.

\section{Results and discussion}

\subsection{Hydrographs and transport of sediments}

Figure 3 presents runoff hydrographs (mean and standard deviation for 4 rain events) and their respective transported sediments for different gradients of the soil flume $(2 \%, 7 \%$ and $14 \%$ ) as a function of storm type (storms moving downstream and upstream, and static storms). It is observed that the distribution of both discharge and soil material transported by runoff depends strongly on the storm type. Due to their reduced variability, the upstream-moving rainfall storms yielded runoff hydrographs with a smaller standard deviation than did other rainfall storm types. The same was found for the soil material transported.

The time to start runoff was affected by both the type of storm and the slope of the soil flume. The time was greater for a flume slope with a smaller gradient. The runoff caused by the downstream-moving rainfall started later, because this event began at the upstream end of the flume. However, due to greater infiltration, it produced a smaller runoff volume than did other rainfall storm types. For this type of event, peak discharge was reached sooner and had a higher value.

The upstream-moving storm was the least erosive storm type, with solid transport being less efficient than other storm types. This can be explained because this kind of storm is characterized by runoff hydrographs with earlier rise, lower peak discharge, less steeply-rising limb, and a longer base time when compared with other storm types. The downstream-moving storm was the most erosive for soil in terms of both the amount of material carried by runoff and the maximum flux of sediments. The effect of the static storm was midway between the other two types.

As seen from Figs. 3 and 4, the soil flume slope had little effect on the hydrograph shape and the peak discharge, but it had a strong influence on the transport of sediments. This is because a steeper gradient increases the transport capacity of runoff, regardless of the storm type.

Table 2 shows the main characteristics of hydrographs and the associated solid transport for slopes and types studied. 
Table 2. Runoff hydrographs and related sediment characteristics for different types of storms and for the 3 slopes studied.

\begin{tabular}{|c|c|c|c|c|c|c|c|c|c|c|c|}
\hline & \multicolumn{2}{|l|}{ Type of Storm: } & \multicolumn{3}{|c|}{ Downstream } & \multicolumn{3}{|c|}{ Upstream } & \multicolumn{3}{|c|}{ Static } \\
\hline & Flume Slope: & & $2 \%$ & $7 \%$ & $14 \%$ & $2 \%$ & $7 \%$ & $14 \%$ & $2 \%$ & $7 \%$ & $14 \%$ \\
\hline \multirow{9}{*}{ 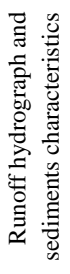 } & Total Runoff Flow (mL) & & 2608.47 & 2960.32 & 2918.17 & 2723.79 & 3079.75 & 2929.98 & 2916.20 & 3157.65 & 3182.12 \\
\hline & Peak Runoff (mL/s) & & 41.35 & 42.31 & 41.45 & 20.73 & 25.28 & 25.55 & 36.13 & 37.58 & 37.41 \\
\hline & Total Sediments Transported (g) & & 8.14 & 46.98 & 105.98 & 6.19 & 12.70 & 39.50 & 5.60 & 29.90 & 91.13 \\
\hline & Peak Sediments Transported $(\mathrm{g} / \mathrm{s})$ & & 0.152 & 0.801 & 1.763 & 0.092 & 0.178 & 0.586 & 0.104 & 0.419 & 1.207 \\
\hline & Time to Peak (s) & & 112.50 & 107.00 & 105.00 & 99.00 & 110.75 & 93.25 & 85.50 & 89.50 & 86.50 \\
\hline & Beginning Runoff Time (s) & & 90.00 & 69.50 & 67.50 & 31.50 & 28.25 & 25.75 & 33.00 & 22.00 & 19.00 \\
\hline & & Sand $(\%)$ & 36.51 & 84.41 & 78.15 & 18.05 & 49.61 & 67.97 & 8.79 & 76.70 & 76.39 \\
\hline & Percentage of sand, silt and clay. & Silt $(\%)$ & 44.11 & 12.15 & 16.52 & 60.98 & 38.57 & 24.26 & 66.36 & 17.22 & 17.00 \\
\hline & & Clay $(\%)$ & 19.38 & 3.44 & 5.33 & 20.97 & 11.82 & 7.77 & 24.85 & 6.08 & 6.61 \\
\hline
\end{tabular}

Note: The sediment transport peak did not always coincide with the peak discharge.
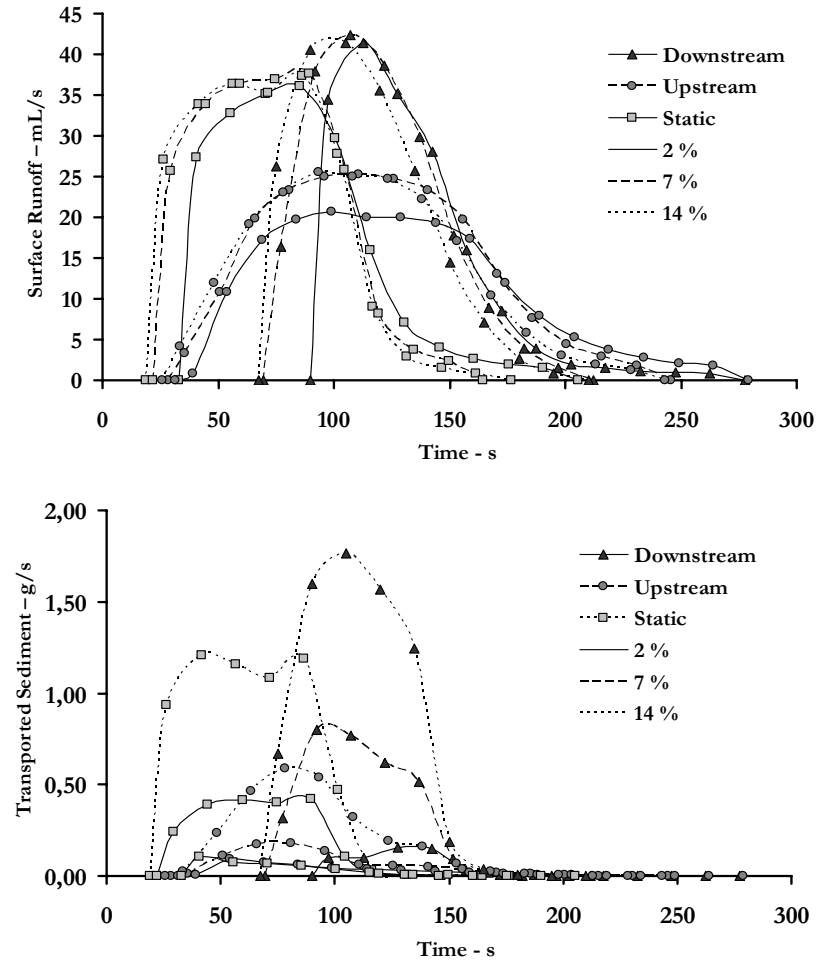

Fig. 4. Comparison of runoff hydrographs and respective eroded material for the different slopes and storm types.

Figure 5 shows the total amount of soil transported by runoff for different storm types and surface gradients studied. It can be concluded that: (i) a steeper slope increases the transported sediments; and (ii) of the various storm types, the downstream-moving storm is the one with the greatest capacity to transport sediments.

Figure 6 shows the values of peak discharge and respective peak sediment flows for different rainfall storms and soil flume gradients. As with the total amount of soil loss, the maximum flow of sediments, for a particular event, was also affected by the storm type and flume gradient. It was ob-

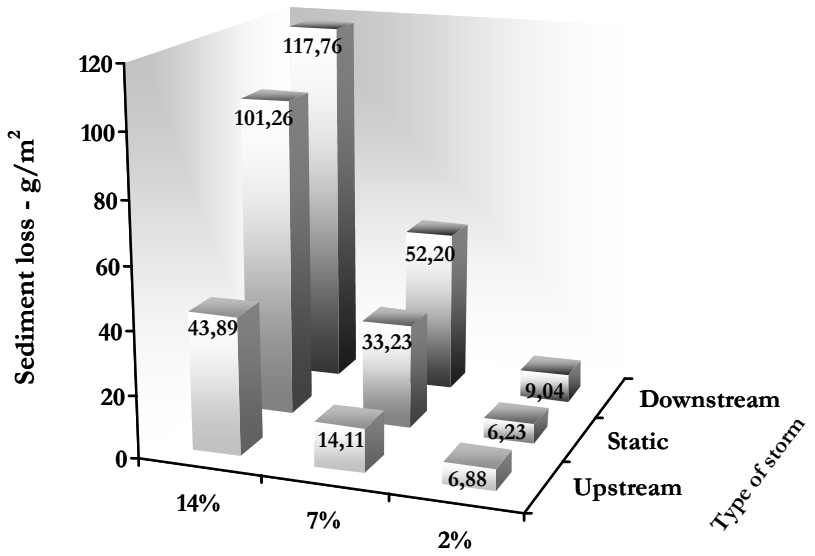

Flume Slope

Fig. 5. Total soil loss caused by different rainfall events as a function of slope and storm type.

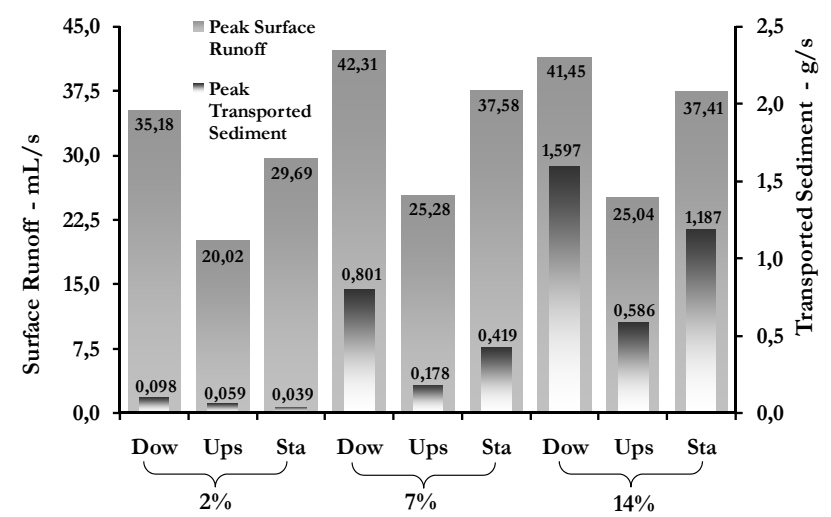

Fig. 6. Peak surface runoff and peak transported sediment for the different storm types (Dow=Downstream; Ups=Upstream; and $\mathrm{Sta}=$ Static) and soil flume slopes (2\%, $7 \%$ and $14 \%)$. 


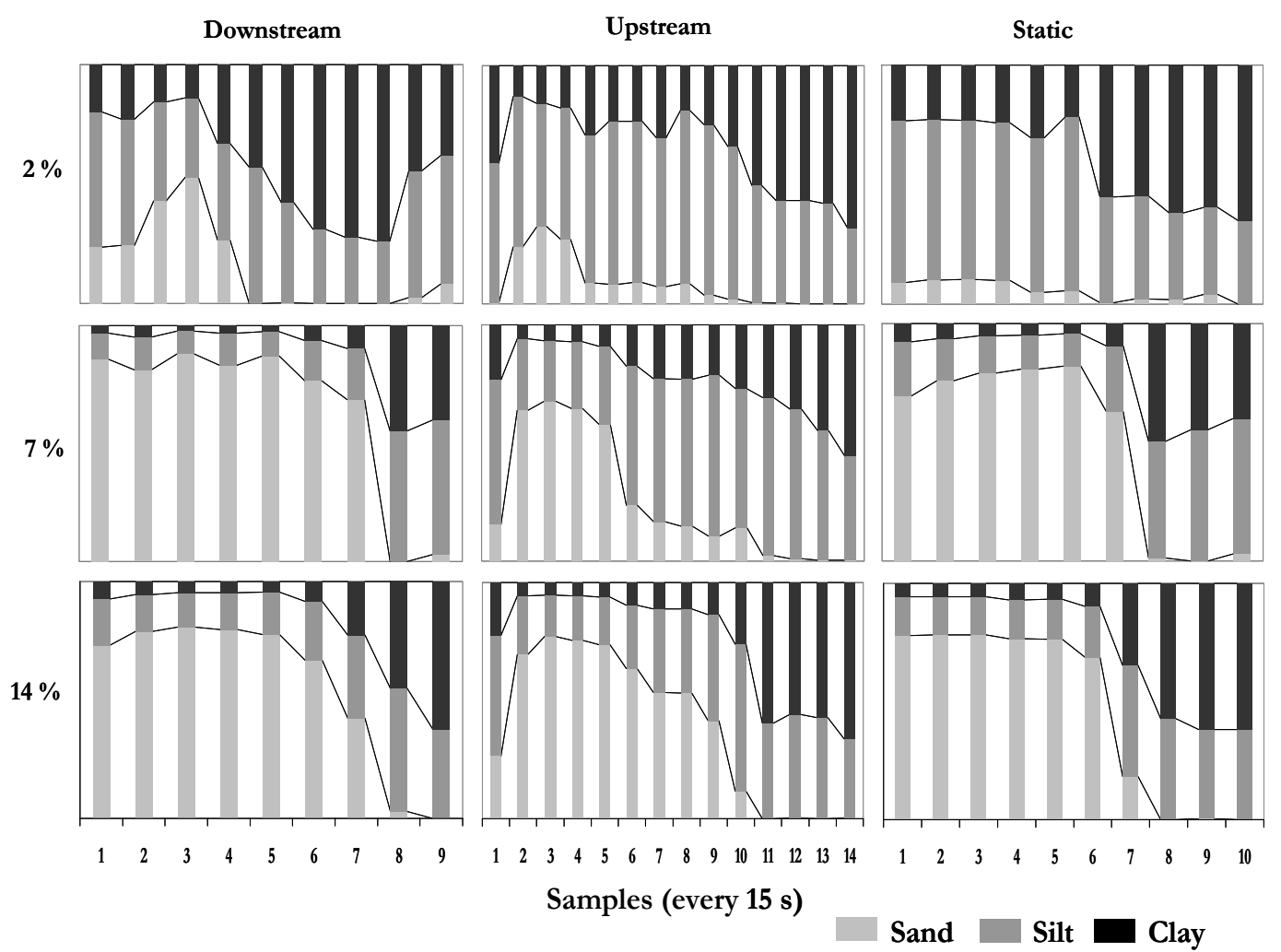

Fig. 7. Granulometric evolution of the collected runoff samples (every $15 \mathrm{~s}$ ), as a function of slope for the three different storm types.

served that: (i) the maximum flow of sediments carried by runoff increased with the flume gradient; (ii) peak discharge was more influenced by the storm type than by the flume gradient, and was greater for the downstream-moving storm than for the upstream moving storm.

\subsection{Grain-size evolution of sediments transported by runoff}

The grain-size evolution of the sediments transported by runoff was investigated. Runoff carried fine material first, and when peak discharge was reached a coarser material was found. In the falling limb of the hydrograph after rainfall ceased, the sediments basically consisted of fine particles because the direct impact of drops was no longer present, strongly reducing the soil detachment capacities of the shallow overland flow sheet. This behaviour was observed for all storm types of storms and flume gradients. However, it was found that the grain-size of the transported sediments was more akin to the original soil when the flume gradient was steeper.

Figure 7 shows the grain-size evolution ( $\%$ sand, $\%$ silt and \% clay) of the transported sediments, collected every $15 \mathrm{~s}$, for different storm types and flume gradients (see also the three last rows of Table 2 for the average values). The percentage of coarse material (sand) increased with steepening flume gradient, due to greater flow energy. It was found that the downstream-moving storm had the greatest capacity to transport coarser material, followed by the static storm and then the upstream-moving storm. It can also be observed that the percentage of sand was greater at peak discharge.

Storm movement also affected the characteristics of sediments transported by overland flow. Figures 8,9 and 10 present granulometric curves of sediments transported by three storm events (rainfall moving downstream and upstream, and static storm), collected at regular time intervals (every $15 \mathrm{~s}$ ) until runoff ceased. The curves show the sediments evolution over time. This behaviour can also be seen in the path observed in the USDA textural classification chart (triangle).

Figures 8, 9 and 10 show that rainfall storms that moved downstream had granulometric curves that were closer to the curve of the original soil. These figures show that the steeper the flume gradient, the greater the amount of coarse material, in both the initial samples and the samples corresponding to peak discharge. Steeper gradient therefore implies an energy increment and thus greater water erosion now characterized not only in terms of sediment weight but also in terms of grain-size distribution. The downstream-moving rainfall storm had a greater erosive power than other rainfall storms for all surface gradients tested. Furthermore, it can be observed that the sediments transported during the upstreammoving storm, regardless of flume gradient, are composed 

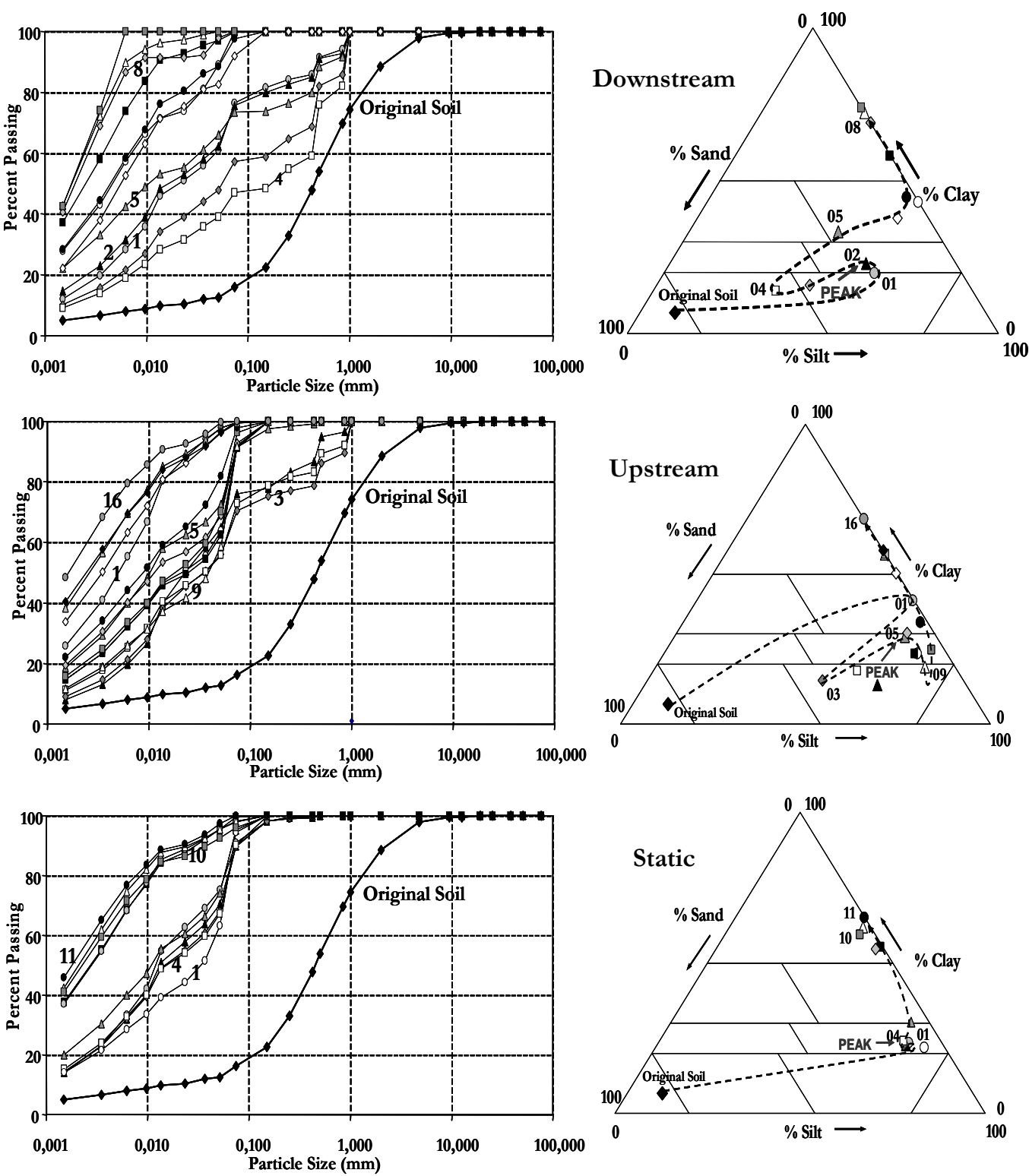

Fig. 8. Granulometric evolution of sediments for $2 \%$ soil flume slope and for 3 storms types: Left: Granulometric curves; and Right: Trajectories in the USDA textural classification chart (triangle).

of finer material (silt and clay). However, this percentage of fine material decreases as the flume gradient increases. As a consequence, the granulometric curves are further away from the curve of the original soil, compared with the other storm types.

Figure 11 shows the granulometric curve relating to the rising and falling limbs and peak discharge for the 3 types of storms and flume gradients studied. It was found that the rising limb and peak discharge had a greater erosive capacity, and were mostly made up of coarser material, regardless of the flume slope. This can be explained by the raindrop impact effects on overland flow transport capacity. Since the kinetic energy of impacting raindrops is much greater than that of shallow overland flow, it is expected that coarser material is mostly transported during the rising limb.

\subsection{Stream power and sediment transport}

Quantification of the relation between surface runoff and sediment transport is important to understand the differences between the static storm and moving storms. These non-linear relations are presented in Fig. 12, for the 3 surface gradients, since slope plays an important role in the processes involved. Consequently, regardless of the soil flume slope, the downstream-moving storm is the storm type that possesses 

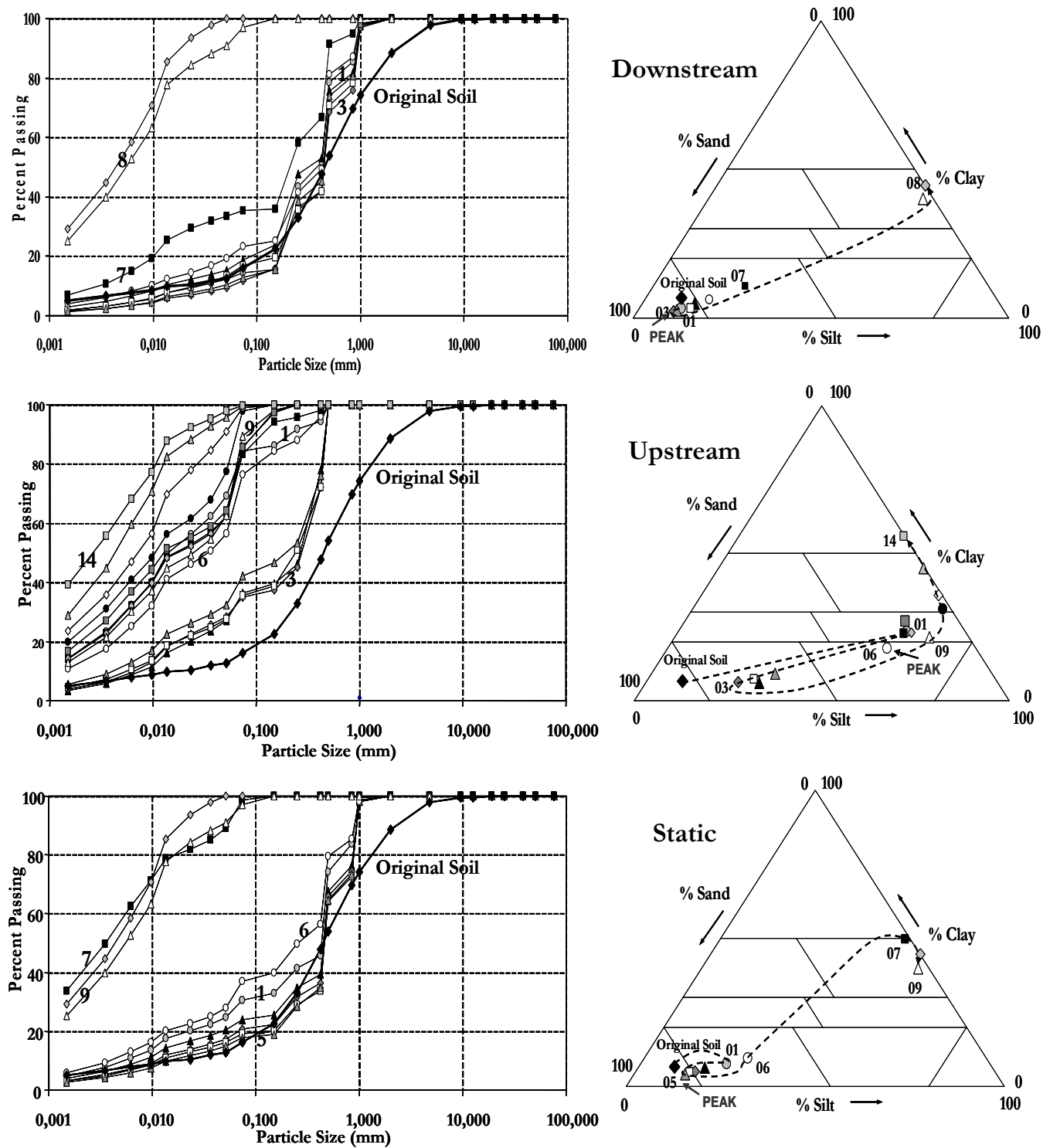

Fig. 9. Granulometric evolution of sediments for $7 \%$ soil flume slope and for 3 storms types: Left: Granulometric curves; and Right: Trajectories in the USDA textural classification chart (triangle).

the highest capacity for the transport of sediments. Static storms have a transport capacity in between downstream and upstream moving storms.

Bagnold (1966) adopted stream power as a theoretical basis for evaluating bedload transport. Since then, stream power has been widely used to better understand such processes in runoff, riverbeds and channels. Stream Power is the energy available to transport sediment. Stream Power per unit length of channel ( $\mathrm{W} \mathrm{m}^{-1}$ ) (e.g., Worthy, 2005; Rose, 2004; Fitzgerald and Bowden, 2006) is:

$\Omega=\gamma Q s$ where $\gamma$ is the specific weight of water $\left(9.810 \mathrm{~N} \mathrm{~m}^{-3}\right), Q$ is the water discharge $\left(\mathrm{m}^{3} \mathrm{~s}^{-1}\right)$, and $s$ is the energy slope $\left(\mathrm{m} \mathrm{m}^{-1}\right)$, which may be approximated by the channel bed slope $\left(s_{0}\right)$.

If we want to determine stream power for a certain short rainfall event (static or moving under wind), we have to consider the variation of runoff, in time, which represent the hydrologic response of the drainage area (the flume surface in these experiments). For the specific laboratory conditions described in this article, stream power can be calculated as:

$\Omega_{T}=\gamma \frac{\sum_{i=1}^{n} \overline{Q_{i}}}{n} s_{0} L$ 

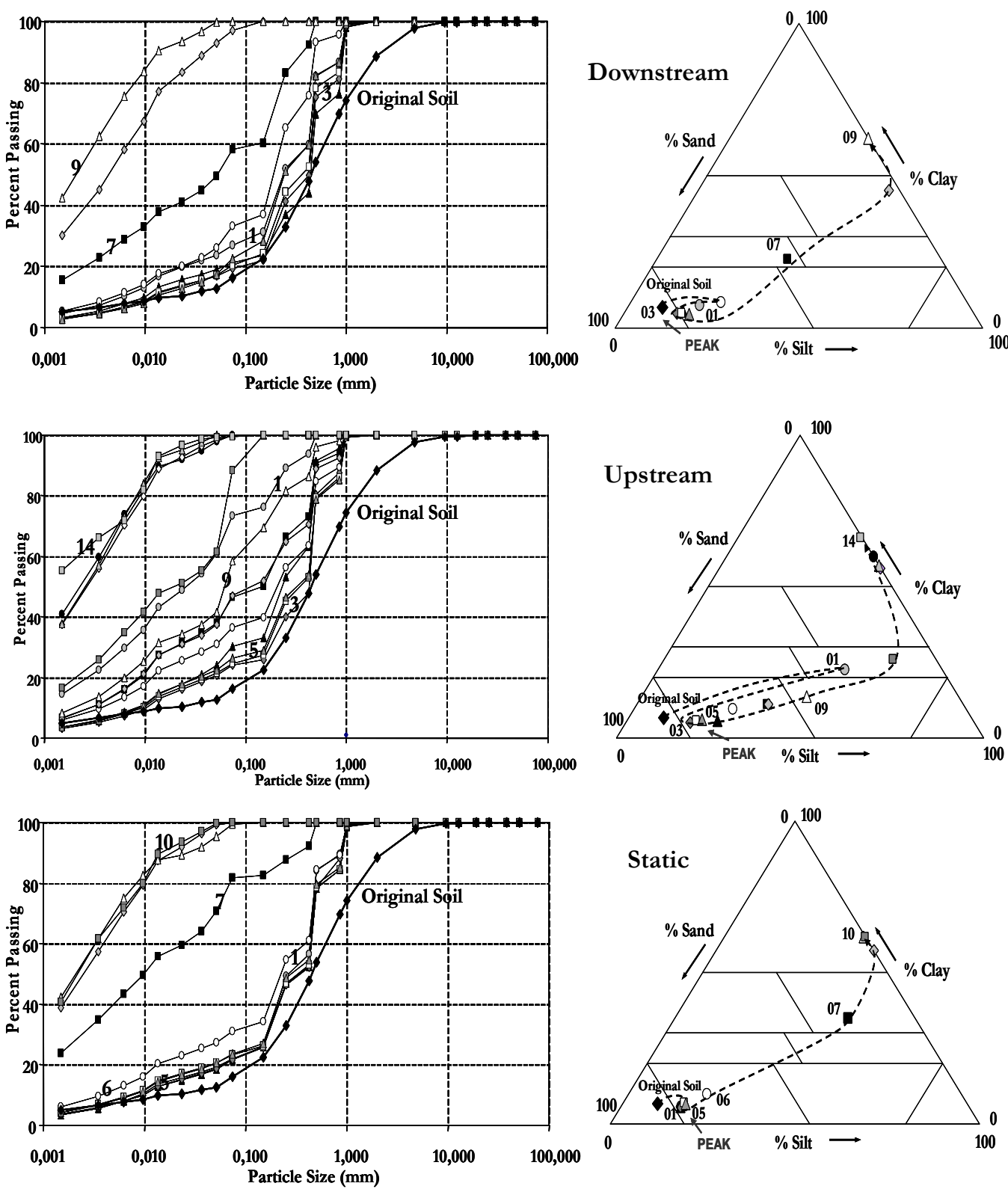

Fig. 10. Granulometric evolution of sediments for $14 \%$ soil flume slope and for 3 storms types: Left: Granulometric curves; and Right: Trajectories in the USDA textural classification chart (triangle).

where $\Omega_{T}$ is the average stream power for the runoff event (W), $\bar{Q}_{i}$ is the water discharge for a sampling time interval of $15 \mathrm{~s}\left(\mathrm{~m}^{3} \mathrm{~s}^{-1}\right), L$ is the slope length (m), which is the length of the flume, $s_{0}$ is the slope of the flume (-) and $n$ is the number of sampling intervals (from the beginning to the end of the runoff hydrograph).

In these experiments we have very shallow overland flow depths and high sediment concentration. It should be noted that the transport capacity of very shallow overland flow is limited and, without raindrop impact, coarse sediments could hardly be transported with these flows (e.g., Moss and Green,
1983; Julien and Simons, 1985; Guy et al., 1987; Kinnell, 1988, 1990 and 1993; Parsons et al., 1998; Zhang et al., 1998). The depth of flow was rather uniform, since significant rills did not appear on the eroding soil surface of the flume.

As water flows down the surface of the flume, the potential energy is converted into kinetic energy. Stream Power is an expression of the rate of energy expenditure or flow strength at a given location. In Fig. 13 stream power is plotted against sediment transported for different storms types and flume slopes. In this figure, the Log-Log relation between stream 

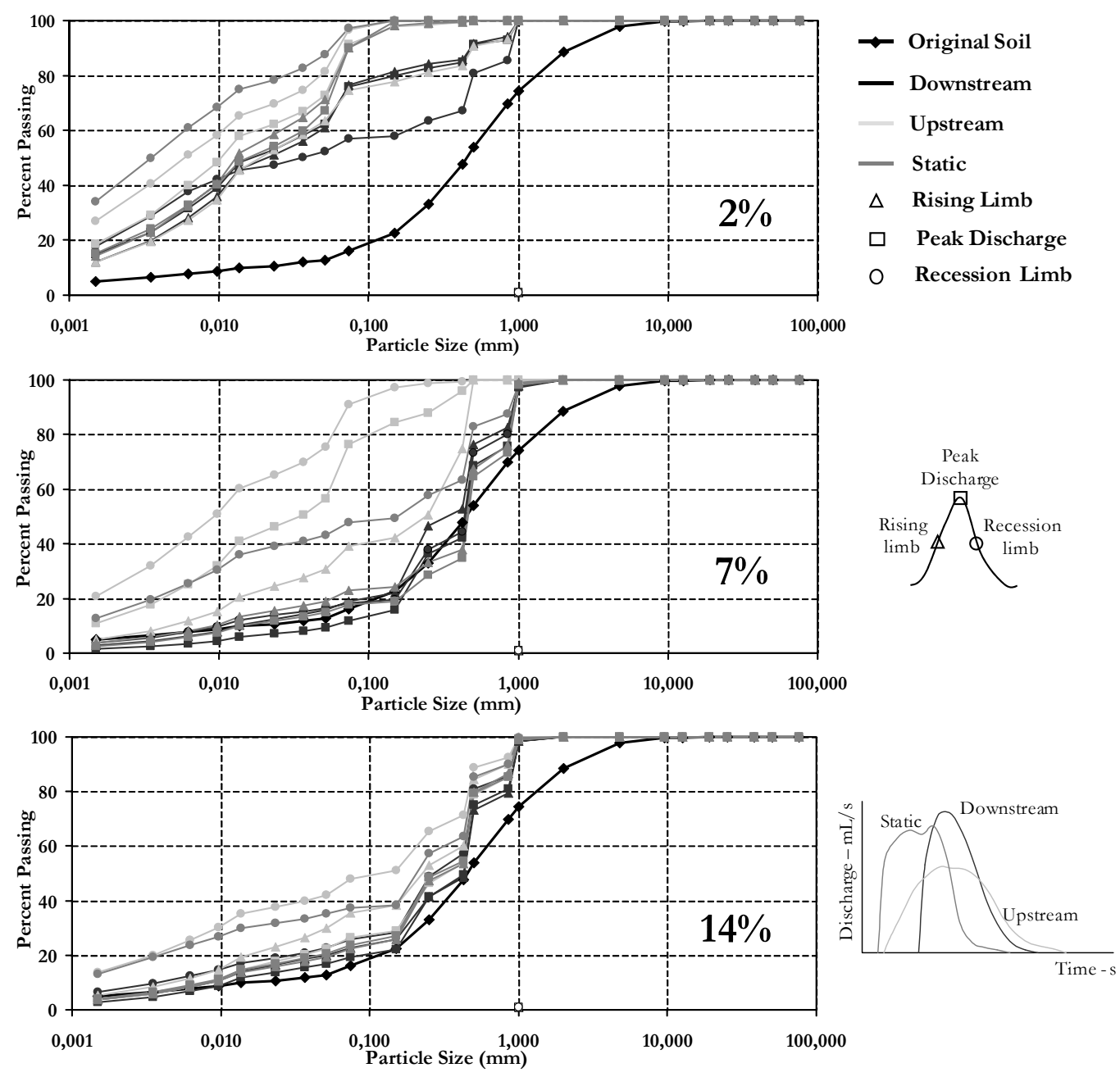

Fig. 11. Granulometric curves referring to as the rising limb and falling limb and the peak discharge of the runoff hydrographs by different storm types and soil flume slopes ( $2 \%, 7 \%$ and $14 \%)$.

power and sediment transport is shown separately for three different slopes, showing approximately a straight line relationship. In this figure all the experimental data are presented, including the three slopes and the three different storm types (for the sampling time interval of $15 \mathrm{~s}$, which generates: 120 points for the downstream moving storms; 176 points for the upstream moving storms; and 130 points for the static storms). The differences between static and moving storms already mentioned are once more clearly noticeable.

Figure 14 shows total stream power as a function of storm type and flume slope. Total stream power increases with flume slope and is higher for downstream-moving storms for a given slope. This is clearly the result of different rising times, peak discharges and base times affecting the sediment transport processes involved.

\section{Conclusions}

The following conclusions can be drawn from this study:

1. Comparing rainfall storms moving downstream and upstream, we find that the latter lead to runoff characterized by hydrographs with: (1) earlier rise, (2) lower peak discharge, (3) less steep rising limb, and (4) greater base time. These conclusions were also reached theoretically and experimentally by several investigators (e.g., Singh, 1998; de Lima and Singh, 1999).

2. The paths (sequence of positions, illustrating evolution in time) in the USDA textural classification chart (triangle) associated with upstream-moving storms are different from the paths associated with downstream-moving storms, with finer grain-sizes at the beginning of runoff, evolving to a coarser size as the peak discharge is approached, and to fine particles in the falling limb of 

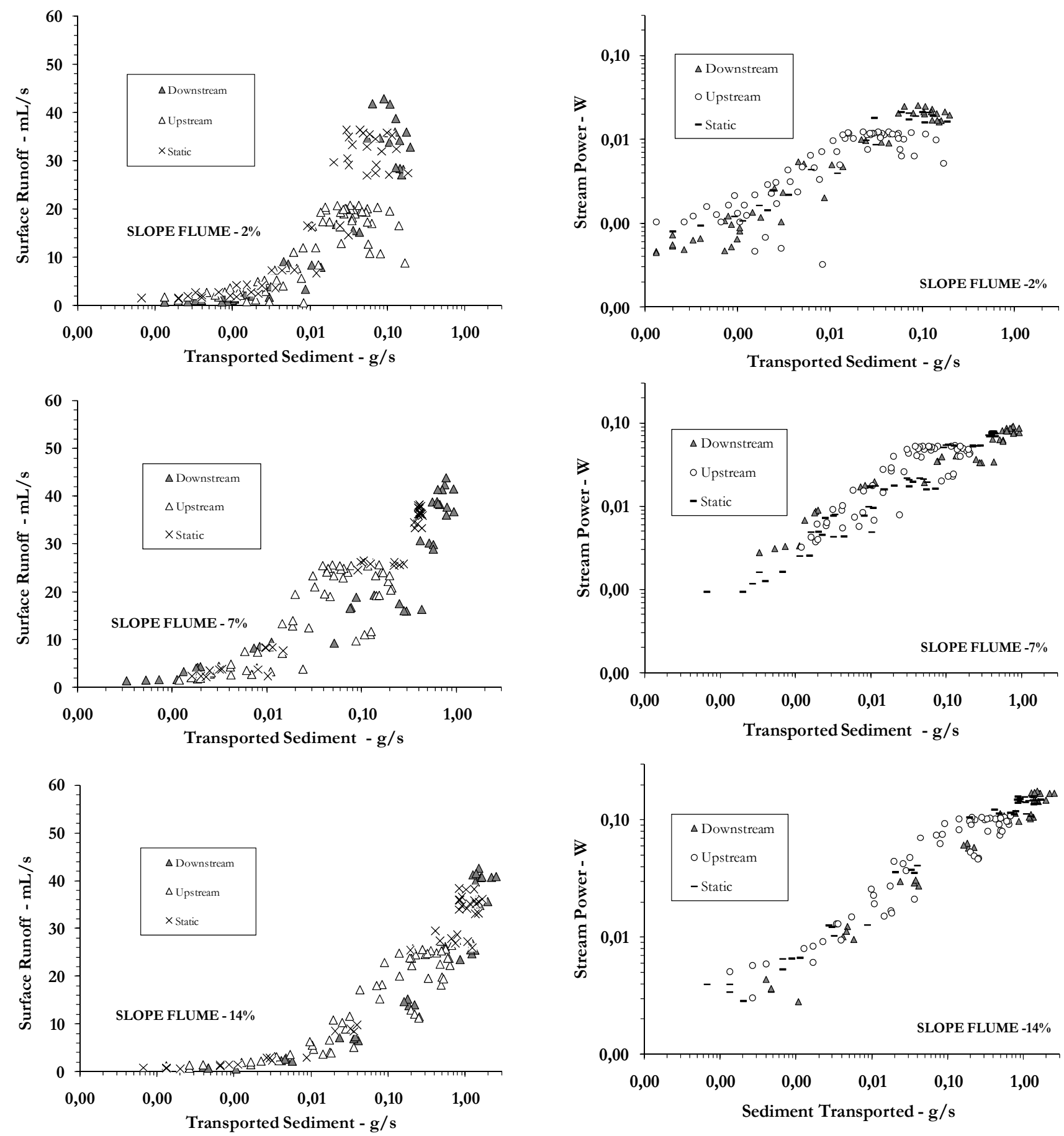

Fig. 12. Relation between the surface runoff and transported sediments as a function of storm type and for the three different flume slopes (applied every 15 seconds and for the 4 repetitions): Top: 2\%; Middle: $7 \%$; and Bottom: $14 \%$.

Fig. 13. Relation between the stream power and transported sediments as a function of storm type and for the three different flume slopes (applied every 15 seconds and for the 4 repetitions): Top: 2\%; Middle: $7 \%$; and Bottom: $14 \%$. 


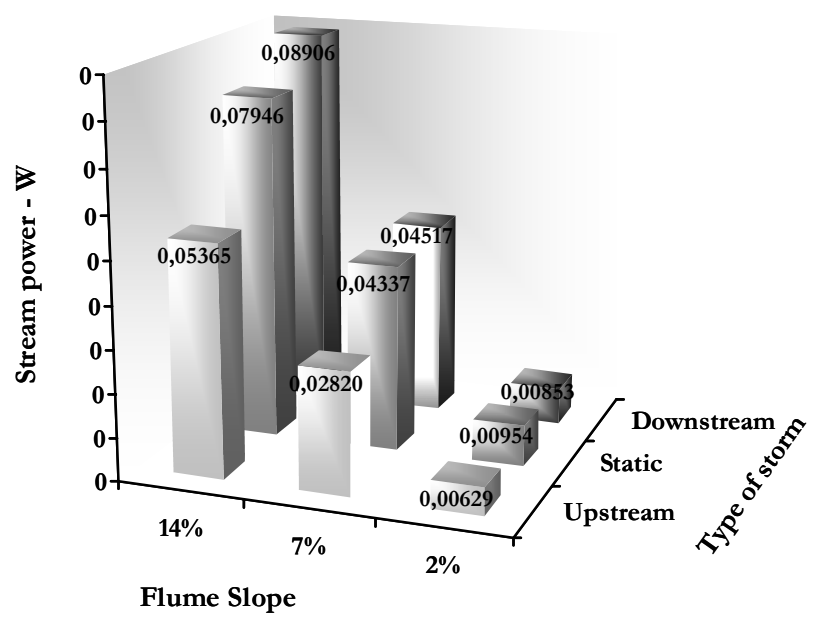

Fig. 14. Stream power as a function of storm type and flume slope.

the hydrograph. The downstream-moving storm with greater initial flow does not evolve in the same way. At first it exhibits a granulometry almost as coarse as the original soil, which then progressively decreases to finer grained sizes.

3. For both the types and flume gradients, the part of the runoff hydrographs that provokes greater soil erosion is the rising limb, as was borne out by the high percentage of coarse material, signifying that the granulometric curve relating to this limb is close to that of the original soil.

4. The downstream-moving rainfall storms have more energy associated with runoff (higher stream power) than do other storm types. Therefore, they are better able to drag coarse particles along, and have the most erosive impact on soil.

5. Stream Power increases with flume gradient; hence a greater percentage of coarse material is carried away. As already reported by other authors, it can be concluded that surface gradient influences solid transport.

Acknowledgements. This study was financed under research project POCI/AMB/58429/2004, by the Foundation for Science and Technology (FCT) of the Ministry of Science and Technology (MCT), approved under the Operational Programme (POCI) of Community Support Framework III (2000-2006) and was carried out in the Hydraulics, Water Resources and Environment Laboratory of the Department of Civil Engineering in the University of Coimbra's Faculty of Sciences and Technology (FCTUC). Some of the experiments reported in this study were carried out with the help of: João Carloto M. Sc., holder of an FCT scholarship; Mr. Joaquim, employee of the Hydraulics Laboratory; Mrs. Manuela of the Laboratory of Sedimentology, and Professors Manuel Azevedo, Pedro de Dinis and Pedro Cunha of the Department of Earth Sciences of the University of Coimbra. The comments of the reviewers helped to improve significantly the paper.
Edited by: W. Krajewski

Reviewed by: M. Elhakeem and another anonymous referee

\section{References}

Bagnold R. A.: An approach to the sediment transport problem from general physics, US Geological Survey Professional Paper, 422-1, 11-137, 1966.

Bras, R. and Rodrigues-Iturbe, I.: Rainfall generation: a nonstationary time-varying multidimensional model, Water Resour. Res., 12(3), 450-454, 1976.

Bryan, R. B. and Poesen, J.: Laboratory experiments on the influence of slope length on runoff, percolation and rill development, Earth Surf. Processes, 14, 211-231, 1989.

Eagleson, P. S.: Climate, soil and vegetation: The distribution of annual rainfall derived from observed storm sequences, Water Resour. Res., 14(5), 713-721, 1978.

Erpul, G., Gabriels, D., and Janssens, D.: Assessing the drop size distribution of simulated rainfall in a wind tunnel, Soil and Tillage Research 45, 455-463, 1998.

Erpul, G., Gabriels, D., and Janssens, D.: The effect of wind on size and energy of small simulated raindrops: a wind tunnel study, International Agrophysics, 14, 1-7, 2000.

Erpul, G., Norton, L. D., and Gabriels, D.: The Effect of Wind on Raindrop Impact and Rainsplash Detachment, Transactions of American Society of Agricultural Engineering, 45(6), 51-62, 2003a.

Erpul, G., Norton, L. D., and Gabriels, D.: Sediment transport from interrill areas under wind-driven rain, J. Hydrol., 276, 184-197, $2003 b$.

Erpul, G., Gabriels, D., and Norton L. D.: Wind effects on sediment transport by raindrop-impacted shallow flow, Earth Surf. Processes, 29, 955-967, 2004

Erpul, G., Gabriels, D., and Norton, L. D.: Sand Detachment by Wind-driven Raindrops, Earth Surf. Processes, 30, 241-250, 2005.

Erpul, G., Gabriels, D., Cornelis, W. M., Samray, H. N., and Guzelordu, T.: Sand detachment under the rains with varying angle of incidence, Catena, 72, 413-422, 2008.

Fitzgerald, E. and Bowden, B.: Quantifying increases in stream power and energy - Using flow duration curves to depict streamflow values, Stormwater, 7(2), 88-94, 2006.

Gabriels, D., Cornelis, W., Pollet, I., Van Coillie, T., and Quessar, M.: The ICE wind tunnel for wind and water erosion studies, Soil Technol., 10, 1-8, 1997.

Guy, B. T., Dickinson W. T., and Rudra R. P.: The roles of rainfall and runoff in the sediment transport capacity of interrill flow, Transactions of the ASAE, 30(5), 1378-1386, 1987.

Huff, F. A.: Time distribution of rainfall in heavy storms, Water Resour. Res., 3(4), 1007-1019, 1967.

Julien, P. Y. and Simons D. B.: Sediment transport capacity of overland flow, Transactions of the ASAE, 28, 755-762, 1985.

Kinnell, P. I. A.: The influence of flow discharge on sediment concentrations in raindrop induced flow transport, Aust. J. Soil Res., 26, 575-582, 1988.

Kinnell, P. I. A.: The mechanics of raindrop-induced flow transport, Aust. J. Soil Res., 28(4), 497-516, 1990. 
Kinnell, P. I. A.: Interrill erodibilities based on the rainfall intensityflow discharge erosivity factor, Aust. J. Soil Res., 31, 319-332, 1993.

de Lima, J. L. M. P. and Singh, V. P.: Laboratory experiments on the influence of storm movement on overland flow, Journal Physics and Chemistry of the Earth, 28(6-7), 277-282, 2003.

de Lima, J. L. M. P. and Singh, V. P.: The influence of the pattern of moving rainstorms on overland flow, Adv. Water Resour., 25(7), 817-828, 2002.

de Lima, J. L. M. P., Singh, V. P., and de Lima, M. I. P.: The influence of storm movement on water erosion: Storm direction and velocity effects, Catena, 52, 39-56, 2003.

de Lima, J. L. M. P. and Singh, V. P.: The influence of storm movement on overland flow - Laboratory experiments under simulated rainfall, in: Hydrologic Modeling, Water Resources Publications, edited by: Singh II, V. P., Won Seo, and Sonu, J. H., 101-111, 1999.

Esteves, M., Planchon, O., Lapetite, J. M., Silvera, N., and Cadet, P.: The "EMIRE" large rainfall simulator: design and field testing”, Earth Surface Process, 25(7), 681-690, 2000.

Maksimov, V. A.: Computing runoff produced by a heavy rainstorm with a moving center, Sov. Hydrol., 5, 510-513, 1964.

Meyer, L. D.: How rainfall intensity affects interrill erosion, Transactions of the American Society of Agricultural Engineer, 24(6), 1472-1475, 1981.

Morgan, R. P. C.: Soil Erosion and Conservation. London, Longman (second edition), 1995.

Moss, A. J. and Green, P.: Movement of solids in air and water by raindrop impact. Effects of drop-size and water-depth variations, Aust. J. Soil Res., 21(3), 373-382, 1983.
Parsons, A. J., Stromberg, S. G. L., and Greener, M.: Sedimenttransport competence of rain-impacted interrill overland flow, Earth Surf. Proc. Land., 23, 365-375, 1998.

Römkens, M. J. M., Prasad, S. N., and Gerits, J. J. P.: Soil erosion modes of sealing soils: a phenomenological study, Soil Technol., 11, 31-41, 1997.

Rose, C. W.: An introduction to the environmental physics of soil, water and watersheds, Cambridge University Press, Cambridge, 2004.

Sharon, D.: The distribution of hydrologically effective rainfall incident on sloping ground, J. Hydrol., 46, 165-188, 1980.

Singh, V. P.: Effect of the direction of storm movement on planar flow, Hydrol. Process., 12, 147-170, 1998.

Sivapalan, M. and Wood, E. F.: A multidimensional model of nonstationary space-time rainfall at the catchment scale, Water Resour. Res., 22(7), 1289-1299,1986.

Willems, P.: A spatial rainfall generator for small spatial scales, J. Hydrol., 252, 126-144, 2001.

Wilson, C. B., Valdes, J. B., and Rodrigues-Iturbe, I.: On the influence of the spatial distribution of rainfall on storm runoff, Water Resour. Res., 15(2), 321-328, 1979.

Worthy, M.: High-resolution total stream power estimates for the Cotter River, Namadgi National Park, Australian Capital Territory, in: Regolith 2005 - Ten Years of CRC LEME. CRC LEME, edited by: Roach, I. C., 338-343, 2005.

Yen, B. C. and Chow, V. T.: A study of surface runoff due to moving rainstorms, Hydraulic Engineering Series No. 17, Department of Civil Engineering, University of Illinois, Urbana, (USA), 1968.

Zhang, X. C., Nearing, M. A., Miller, W. P., Norton, L. D., and West, L. T.: Modeling interrill sediment delivery, Soil Sci. Soc. Am. J., 62, 438-444, 1998. 